\title{
The Perception of Lectures and Working Students Toward English Proficiency
}

\author{
Alpino Susanto ${ }^{1}$, Berhannudin Mohd Salleh², Fazlinda Ab Halim ${ }^{3}$ \\ Universitas Karimun, Indonesia ${ }^{1}$ \\ Universiti Tun Hussein Onn, Malaysia, ${ }^{2,3}$ \\ susanto.alpino40@gmail.com ${ }^{1}$
}

\begin{abstract}
The growing of University is counted on the successfulness of its alumni to sail through different levels of their career. Generally, English is viewed as a subject imposed on the University curriculum for the students' future career. This study is considered as preliminary findings of English proficiency of the student worker. The primary objective is to elaborate the lecturers' and students' perceptions towards students' English proficiency. The interview and questionnaire were conducted in Batam, Indonesia. This reports the perceptions obtained from the lecturers and students based on the following themes: their general knowledge in English as foreign language subject, strength, weakness and overall achievement. There were 9 English lecturers and 39 students participated on the semi structure questionnaire based in the four universities in Batam. The research revealed various phenomena of students' weakness and strength in learning English in the context of Batam. The motivation and vocabulary are the two-major variable need more attention on the English subject among student worker.
\end{abstract}

Keywords: Perception, English Proficiency, Working student, Strength, Weakness.

\section{Introduction}

We are in globalization era in which the need for a common language is deeply and strongly felt more than ever before. Nothing else to say, the language is English, with an unprecedented spread all around the world and in many domains and parties. Yet, it is a truism that English fulfills the task of bridging people who have nothing in common to be part of global knowledge. One of the domains where English widely prevails, beyond doubt, is the tertiary level students. In this level, English as a foreign language subject is expected can play role through students' proficiency in various sector soon they graduate.

Globally, [1] rightly points out that English has long been the language in university, particularly in those universities that are outward looking for establishing international ties. Naturally, many universities, also through the effects of rapid process of internationalization, have worried about their students' English proficiency and motivation since this subject offered. The process of integrating of the international dimension into the teaching, research and service functions of the universities is to switch to English as the language of instruction, either wholly or partly on campus [2]. Yet, in the context of Indonesian where English is as 
foreign language, the phase still needs to consider some aspects, such as lecturers' readiness and students' capability. All the target way of English teaching is to synchronize the teaching instruction and learner capability. Student proficiency in the English language is important in this era of communication as it is the language of scientific and technological papers, and this situation will continue to on demand.

In the current work and education landscape, sometimes it becomes increasingly difficult to see where work starts and study begins. In Batam, more than $50 \%$ of students are worker. A huge fraction of persons describing themselves as "students who work" work fulltime or more, and likewise a large proportion of those self-reporting as "workers who study" work part-time and go to school on a full-time basis [3]. This phenomenon could be linked to the handicap of English as a foreign language learners face in all four English skills, including their sub-skills have been a very hot topic for research since English Language proficiency is currently a requirement in many aspects of work and study [4]-[10]

Elaborating the perceptions of English lecturer about their students' English proficiency, strength and weakness are important, as that could be the base of further investigation need. The students' perception about their capability in English as the subject in their University could strengthen the finding. [11] emphasize that English lecturers' perception upon their students may influence how well their student perform toward the subject. The lecturer perception upon their students' English proficiency is considered as the base information to describe the real phenomenon of English learning among tertiary level students before further investigation to be done. As the English increasingly plays an important role to students who work, which through communication processes and influences labor productivity as argued by [12]. Workers' language capability could facilitate their communication with superiors and colleagues, leading to better coordination in the workplace. On the contrary, the lack of English skill could force individuals to work in positions below their productivities, [13]. Since English language acquisition is an integral part of human capital building up, Batam student workers whose proficiency is unfortunately at a low level could thus face the competitive challenge from other labors in this zone.

The important of English could also be seen not only from the practicality of the proficiency in their job site for the student worker. The important role of English subject was pointed out by Indonesian government through the current laws of National education system in Indonesia (the 1989 Education law No.2 and the 1999 Government Regulation on Higher Education No.60). Education at the tertiary level is mainly designed for profession building. The students in higher education prepared to take specific and major subjects to support their future profession. However, they are still required to take the mandatory subjects called general education courses and English is one of them. In some campuses in Batam, the subject graded 1 and 2, or overall four credits or two separated subjects. English that is to be functioned not only as effective and efficient means of interaction but also as the medium of instruction. Moreover, English is included to develop and disseminate the technology and arts that would uplift the quality of life enhanced by the national cultures. The English as a subject is General English that basically aiming at students' competency.

The question that has the paramount importance are how the perception of English lecturers and students upon the students' English proficiency. The students' English proficiency has been unheard of number, and this is the benefit of doing initial research and finding in this foreign language context. The perceptions of individuals about language learning, their strength and weakness in learning the language, and the feelings they have of themselves may influence how well they will eventually learn the language [11]. Moreover, It is important to seize the unavailability of empirical data phenomenon of Batam tertiary level 
student, which mostly the students characteristic as worker. The results of this study would give some information for lecturer, researcher, and university management bodies on the attention aspect of English learning on the student worker context.

\section{Method}

This study adopts the qualitative approach to data collection and analysis. Quantitative statistics is utilized to describe the percentile of the perception. The first phase the researcher interviewed the English lecturers about their perception upon the students' English proficiency. The next phase was to get students' perception on their English proficiency. A simple set of questionnaire were distributed to the students.

The researchers started a semi-structure interview to probe the lecturers' perception on their student English proficiency. Mentioned that the mainly used of finding out what is in and on someone else's mind is through interview. The interview has been found to be widely used in needs analysis particularly as it is more flexible in the sense that the order and wording of the questions. In this, type of interview can be changed based on the direction of the interview and the interviewer's discretion. This indicates that there are more reliable in valid responses about the participants' perception, experiences and real life [14].

The researcher followed the following interview protocol: the interviewees were assured that the interview data would be kept confidential and used only for the purpose of this research study. Therefore as per the overall requirement, the name of campuses and interviewee were to be hided, but coded. They were asked to provide some general information to make them feel relaxed. They were informed that interview contains questions regarding their perception and opinion about their students' English learning situation. The lecturer as participants can stop the recorder anytime they want and refuse to answer any of the interview questions if they were not comfortable responding to it. They were able to direct any questions related to this research. The interviews were audio-recorded and transcribed and their content, then to be grouped accordingly.

The interviews were conducted during the beginning of first semester 2017. All English lecturers from 4 universities in Batam were encouraged to participate, and there were 9 lecturers participated on the interview.

The researcher used semi-interview questionnaire to the lecturer with four questions:

1. What do you think about your students' English proficiency?

2. Which aspects of English learning do you think of student's strength?

3. Which aspects of English learning do you think of student's weakness?

4. If you score your student in the range of 1 to 10 , in which level of your student's English ability is on average?

Table 1 specify the participant performance from lecturer. The lecturers participated in the study were from four universities in Batam. The experience of the lecturer range from 1.5 to 7 years. The experience of the lecturer counted on the campus life in Batam only started in the last seven years.

Table 1. Lecturer Participant Profile

\begin{tabular}{|c|c|c|c|}
\hline University & $\begin{array}{c}\text { Number of } \\
\text { lecturer }\end{array}$ & $\begin{array}{l}\text { Respondent } \\
\text { code }\end{array}$ & $\begin{array}{l}\text { Participant lecturers' } \\
\text { teaching experience }\end{array}$ \\
\hline \multirow{2}{*}{ A } & \multirow{2}{*}{2} & A1 & 1.5 year \\
\hline & & $\mathrm{A} 2$ & 2 years \\
\hline \multirow{2}{*}{ B } & \multirow{2}{*}{3} & B3 & 5 years \\
\hline & & B4 & 5 years \\
\hline
\end{tabular}




\begin{tabular}{|c|c|c|c|}
\hline & & B5 & 2 years \\
\hline \multirow{3}{*}{$\mathrm{C}$} & \multirow{3}{*}{3} & C6 & 7 years \\
\cline { 3 - 4 } & & C7 & 2 years \\
\cline { 3 - 4 } & & C8 & 3 years \\
\hline D & 1 & D9 & 7 years \\
\hline
\end{tabular}

The researcher delivered the four questions to students in written text and they were to choose the perception as per the feeling they were. Questionnaire to the students:

1. My knowledge in English, 3= high, 2=medium, 1=low

2. I have strength in English, 3=Agree, 2=neutral, 1=do not agree

3. I have weakness in English, $3=$ Agree, $2=$ neutral, $1=$ do not agree

4. Overall score in English subject

The students were also requested to specify their strength and weakness, the most.

\section{Discussion}

The findings from this study are further elaborated in four main parts, first related Lecturers' and students' perception on students' English proficiency. The second was about the lecturers' and students' perception toward student's strength in learning English. The third was about their perception toward the students' weakness in learning English. The fourth was their overall scoring toward the students' ability in English. Each part of the findings were further discussed in reference to what theories and previous related studies have said.

\subsection{Lecturers' Perception on Their Students' English Proficiency}

Researcher interviewed one by one of the 9 lecturers and then record their voice. The questions were asked to the lecturers to get their perception upon their students' English proficiency. There were six lecturers considered that their students have issue in their English proficiency. E.g. lecturer A1 stated “..most of them didn't even have much English classes before, so as consequence, they were struggling in my class...". The six lecturers stated their students have low English proficiency in term of grammar and vocabulary. However, there were three lecturers considered their students' English proficiency were good and had no issue.

The second question was to know the students' strength from lecturers' perception. Almost all of the lecturer perceived that their students were good in motivation, unless one lecture stated that he did not see the strength. As quoted from the A1 "I cannot really see what are their strong points at the moment because we are still working at the basic".

The lecturer's perception upon students' weakness varied but overall they concerned on the students vocabulary, got tired during the class subject, writing ability, anxiety, and grammar. There were three lecturers commented that their students' weakness were in vocabulary. E.g., one of the lecturer stated "They just don't have enough words to allow them to speak and as well as to write in English".

The lecturer perception upon the students' score were figured out on the figure 1 . The perception is based on the lecturer overall performance during the teaching and learning process in English subject. The lecturer perception was based on their observation and experience deal with students overall performance. All the perception score from the lecturer placed their students below the minimum target. 


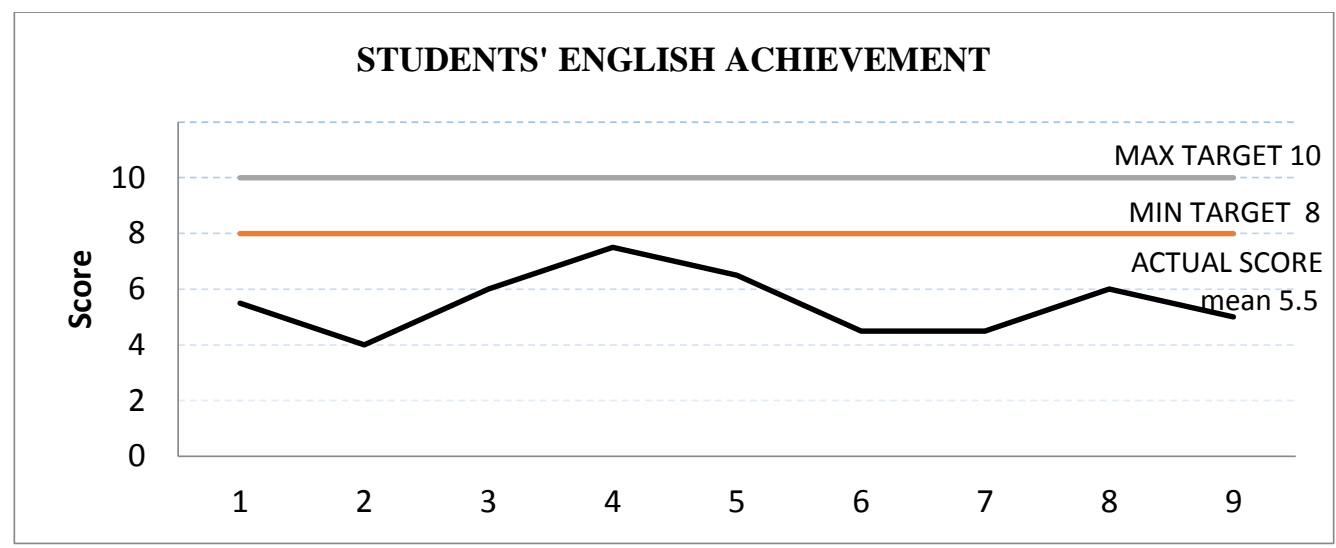

Fig. 1. English Student Achievement.

\subsection{Students' perception on their strength and weakness}

Students' perception on their own strength and weakness are summarized on table 2. The students' perception grouped and rated per university (coded A, B, C, and D. The table contains the summary of students' statement in term of their strength and weakness.

Table 2. Students Perception on Their English Proficiency

\begin{tabular}{|c|c|c|c|c|c|c|}
\hline Participant & Strength & Weakness & $\begin{array}{c}\text { Statement } \\
1 \\
\end{array}$ & \begin{tabular}{|c|} 
Statement \\
2 \\
\end{tabular} & \begin{tabular}{|c|} 
Statement \\
3 \\
\end{tabular} & \begin{tabular}{|c|} 
Statement \\
4 \\
\end{tabular} \\
\hline $\begin{array}{l}\text { University A } \\
10 \text { students }\end{array}$ & $\begin{array}{l}\text { High motivation, never } \\
\text { fail English subject, \& } \\
\text { speaking }\end{array}$ & $\begin{array}{l}\text { Limited vocabulary, } \\
\text { grammar, \& reading }\end{array}$ & 1.7 & 2 & 2.2 & 2 \\
\hline $\begin{array}{c}\text { University B } \\
10 \text { students }\end{array}$ & $\begin{array}{l}\text { High motivation \& } \\
\text { never fail English } \\
\text { subject }\end{array}$ & $\begin{array}{l}\text { Limited vocabulary, } \\
\text { reading, grammar, } \\
\text { listening, \& writing }\end{array}$ & 1.7 & 1.2 & 2.1 & 1.9 \\
\hline $\begin{array}{c}\text { University C } \\
10 \text { students }\end{array}$ & $\begin{array}{l}\text { High motivation \& } \\
\text { never fail English } \\
\text { subject }\end{array}$ & $\begin{array}{c}\text { Grammar, listening, \& } \\
\text { writing }\end{array}$ & 1.8 & 1.8 & 1.9 & 2 \\
\hline $\begin{array}{c}\text { University D } \\
9 \text { students }\end{array}$ & $\begin{array}{l}\text { High motivation \& } \\
\text { speaking }\end{array}$ & $\begin{array}{l}\text { limited vocabulary, } \\
\text { grammar, speaking, } \\
\text { listening, \& reading }\end{array}$ & 1.3 & 2.1 & 2.4 & 2 \\
\hline & & Mean score $\rightarrow$ & 1.6 & 1.7 & 2.1 & 1.9 \\
\hline
\end{tabular}

\section{Summary}

The research finding and discussion have given an account of lecturers' and students' perception on the students' English proficiency. From the lecturers' perception on the 
students' English proficiency, six from nine lecturers have concern on their students' English proficiency. The disadvantages were indicated from their performance during the English subject taken.

The Lecturers' perception on the strength contemplate the level of students' motivation. The students' working experience indicated the positive impression to the lecturer. As student worker, the productive skill of them more or less help them during the learning process. The lecturers' perception on the weakness center around on the recognition of the complexities in assessing English skills, the main one is vocabulary, and the students' time management between working and studying. Lecturer expressed confidence in assessing clinical skills and tasks but from the students' part, the lacked time and anxiety in assessing language learning process are domain.

Students' perception on their performance indicated the weakness of their English subject. It is worth to mention that the students' perception on English matched with Lecturers' perception. Hence, although the perception categorized as lower achievers based on data obtained, the lecturer and student statement on their strength was mostly on motivation.

\section{Conclusion}

A lot more investigation needs to be carried out, so these notes of this small research should be seen as an invitation, and perhaps the beginning of a framework within which to begin recognize the student-workers inquiries in English proficiency. Looking at from 39 students responded majority had weakness in English subject. Preceded by their lecturers' respond the students' English proficiency are weak. The respond were limited vocabulary, speaking, writing, reading, listening and grammar. Limited vocabulary was the most frequent responded.

\subsection{Motivation is Strength Point}

Majority of lecturers believed that their students were having positive motivation about English subject, meant a significant positive role to play in their future development and were committed to taking up the challenge to become proficient in it. Furthermore, the role of the teaching approach in raising motivation cannot be ignored. This approach was preliminary exploration on the students phenomena in particular city named Batam in the fact that there was a deliberate effort to 'teach' the importance of English to development and a conscious use of various activities often ignored by lecturers due to difficult teaching conditions. Mostly the students were worker and in fact the perception from either lecturer or among the students, English was the subject that they have high willingness to achieve as well as they are weak on it.

\subsection{Vocabulary is the Weakness}

Student worker is the phenomena in this city. One can say that, in many cases, the teaching and learning of English in University participated by mostly students worker has been viewed mainly as a means of immediate academic advancement. Lecturers are aware that their students are worker. The purpose of studying English should go beyond success in examinations. In comparison of Lecturers' perception on students general knowledge of English versus students. Further research can be conducted to identify the students' English progress academically, this will lead to good jobs (even at the local level) and improved standards of teaching and learning.

\subsection{Student-worker}


Student worker have positive impact as well as negative. Mostly those who spent the time on the job task the whole day get slowly at the rest of the day. If the job leads them to international environment the impact is positive. Those who can use English to acquire more knowledge and information and to relate with others all over the world become personally and socially empowered. But if mostly the job involve the physical activities, the students tend to get tired at the end of office hour coming to the class session.

\section{References}

[1] C. Brumfit and R. Mitchel, "The language classroom as a focus for research," in Research in the language classroom, C. Brumfit and R. Michell, Eds. Hongkong: Modern English Publications, pp. 3-15.

[2] J. Rochecouste, R. Oliver, and D. Mulligan, "English language growth after university entry," Int. J. Educ. Res., vol. 53, pp. 1-8.

[3] M. Bousquet, How the University Works: Higher Education and the Low-wage Nation. New York: NYU Press.

[4] D. Adas and A. Bakir, "Writing Difficulties and New Solutions: Blended Learning as an Approach to Improve Writing Abilities," Int. J. Humanit. Soc. Sci., vol. 3, no. 9, pp. 254-266.

[5] S. Asassfeh, Y. Al-Shaboul, W. Zuraiq, and S. Alshboul, "Lending Ears to EFL Learners: Language Difficulties," Aust. Educ. Dev. Psychol., vol. 28, no. 1, pp. 33-46.

[6] L. Detawy, "Problems Encountered by Arab EFL Learners," in Language in India, vol. 11, no. 3, pp. 19-27.

[7] A. Alkhawaldeh, "The Challenges Faced by Jordanian English Language Teachers at Amman 1st and 2nd," Dir. Educ. Coll. Student J., vol. 44, no. 4, pp. 1-30.

[8] K. Mourtaga, "Some Reading Problems of Arab EFL Students," J. Al-Aqsa Univ., vol. 10, no. 2, pp. 75-91.

[9] G. Rababah, An investigation into the strategic competence of Arab learners of English at Jordanian universities. Unpublished PhD dissertation. University of Newcastle upon Tyne. UK.

[10] Y. Chen, "The Problems of University EFL Writing in Taiwan. The Korea TESOL," Journal, vol. 5, pp. 59-79.

[11] C. S. C. and T. S, "An Investigation into the Changes in Perceptions of and Attitudes Towards Learning English in a Malaysian," Coll. Int. J. Teach. Learn. High. Educ., vol. 18 , no. 2, pp. 120-130.

[12] Kim, "Korean Professor and Student Perceptions of the Efficacy of English-Medium Instruction," Linguist. Res., vol. 28, no. 3, pp. 711-741.

[13] D. W. Engstrom, L. Gamble, and J. W. Min, "Field Practicum Experiences of Bilingual Social Work Students Working with Limited English Proficiency Clients," Joumal Soc. Work Educ., vol. 45, no. 2, pp. 209-224.

[14] K. Punch, Introduction to Social Research: Quantitative and qualitative Approaches. London: Sage. 